Jurnal Akuntansi Bisnis, Vol. 19, No. 1, Maret 2021

ISSN 1412-775X (media cetak) | 2541-5204 (media online)

\title{
Pengaruh Struktur Aset, Risiko Bisnis, dan Pertumbuhan Penjualan Terhadap Struktur Modal Dengan Profitabilitas Sebagai Variabel Moderating
}

\author{
Usi Meilani ${ }^{1}$ \\ Agus Wahyudin ${ }^{2 *}$ \\ 1,2 Jurusan Akuntansi, Fakultas Ekonomi, Universitas Negeri Semarang \\ *Corresponding Author Email : usi.mei28@gmail.com
}

\begin{abstract}
This study aims to analyze and describe the effect of asset structure, business risk and sales growth on capital structure by using profitability as a moderating variable in property and real estate companies listed on the Indonesia Stock Exchange in 2017-2019. The sample of this research is 49 companies with 147 units of analysis. The sampling method used is purposive sampling. The data collection technique in this study uses the documentation technique in the form of company financial statement data. Data were analyzed using descriptive statistical analysis techniques and inferential statistical analysis with Moderated Regression Analysis (MRA). Data analysis was performed using IBM SPSS Statistics 23. The results of this study indicate that asset structure has a positive and significant effect on capital structure. Business risk and sales growth have no effect on the capital structure. Profitability is able to moderate the effect of asset structure and business risk on capital structure but is unable to moderate the effect of sales growth on capital structure. Business risk and sales growth have no effect on the capital structure. Profitability is able to moderate the effect of asset structure and business risk on capital structure but is unable to moderate the effect of sales growth on capital structure. Business risk and sales growth have no effect on the capital structure. Profitability is able to moderate the effect of asset structure and business risk on capital structure but is unable to moderate the effect of sales growth on capital structure.
\end{abstract}

Keywords: Capital structure, profitability, asset structure, business risk, sales growth

\begin{abstract}
Abstrak
Penelitian ini bertujuan untuk menganalisis dan mendeskripsikan pengaruh struktur aset, risiko bisnis dan pertumbuhan penjualan terhadap struktur modal dengan menggunakan profitabilitas sebagai variabel moderating pada perusahaan properti dan real estat yang terdaftar di BEI tahun 2017-2019. Sampel penelitian ini sebanyak 49 perusahaan dengan 147 unit analisis. Teknik pengambilan sampel yang digunakan adalah purposive sampling. Teknik pengumpulan data dalam penelitian ini menggunakan teknik dokumentasi berupa data laporan keuangan perusahaan. Data dianalisis dengan menggunakan teknik analisis statistik deskriptif dan analisis statistika inferensial dengan Moderated Regresion Analysis (MRA) Analisis data dilakukan dengan menggunakan IBM SPSS Statistics 23. Hasil dari penelitian ini menunjukkan bahwa struktur aset memiliki pengaruh positif dan signifikan terhadap struktur modal. Risiko bisnis dan pertumbuhan penjualan tidak memiliki pengaruh terhadap struktur modal. Profitabilitas mampu memoderasi pengaruh struktur aset dan risiko bisnis terhadap struktur modal namun tidak mampu memoderasi pengaruh pertumbuhan penjualan terhadap struktur modal.
\end{abstract}

Kata kunci: Struktur modal, profitabilitas, struktur aset, risiko bisnis, pertumbuhan penjualan 
Jurnal Akuntansi Bisnis, Vol. 19, No. 1, Maret 2021

ISSN 1412-775X (media cetak) | 2541-5204 (media online)

\section{PENDAHULUAN}

Modal merupakan sumber dana yang digunakan untuk membiayai pengadaan aset dan membiayai kegiatan operasional perusahaan. Menurut Riyanto (2001) sumber dana dalam pemenuhan struktur modal berasal dari sumber dana internal maupun sumber dana eksternal. Sumber dana internal atau modal sendiri diperoleh dari setoran pemilik dan hasil operasi perusahaan. Sedangkan sumber dana eksternal atau modal asing diperoleh dari pinjaman atau hutang dan penjualan saham.

Ketetapan pendanaan atau kebijakan struktur modal merupakan bagian dari fungsi manajemen keuangan. Manajer keuangan harus mampu mempertimbangkan dan menganalisis pengelolaan keuangan dari dana internal dan dana eksternal agar memperoleh struktur pendanaan yang optimal. Menurut Eldomiaty dan Ismail (2009) struktur modal yang optimal merupakan suatu penentuan perpaduan yang cocok dari pemakaian dana jangka panjang yang dapat mengurangi biaya modal sehingga dapat mengoptimalkan nilai perusahaan. Optimalnya struktur modal akan mengakibatkan efisiensi biaya modal. Efisiensi modal akan membuat harga saham naik dan membuat naiknya nilai perusahaan (Rustam, 2015).

Penggunaan hutang yang tinggi dalam struktur modal perusahaan mengakibatkan perusahaan properti dan real estat memiliki risiko yang lebih tinggi. Perusahaan harus mampu menyesuaikan risiko dan manfaat dari penggunaan hutang dalam stuktur modalnya. Tingginya hutang dapat mengakibatkan risiko kesulitan keuangan, turunnya harga saham hingga kebangkrutan. Perusahaan properti dan real estate yang mengalami penurunan harga saham akibat penggunaan hutang yang tinggi adalah PT Binakarya Jaya Abadi mengalami penurunan harga saham sebesar 24,48 persen dengan harga sebelumnya Rp.192 menjadi Rp.145 per lembar saham dan membuat perusahaan ini menempati urutan pertama dalam sepuluh daftar perusahaan dengan saham terlemah di BEI ( http://market.bisnis.com, 2019). Hal ini akan mengakibatkan menurunnya investor yang tertarik untuk berinvestasi dikarenakan investasi dianggap tidak menguntungkan dan berisiko.

Beberapa perusahaan properti dan real estate mengalami penurunan rating oleh Fitch. Fitch merupakan lembaga penilai kredit, lembaga ini bertugas menilai kemampuan perusahaan dalam melunasi kredit atau hutangnya. Salah satu perusahaan yang mengalami penurunan rating oleh Fitch yaitu PT Alam Sutera Realty Tbk (ASRI) yang mengalami penurunan rating dari B- menjadi CCC- atau mengalami penurunan dari tingkat kurang sehat menjadi tidak sehat. Pada tahun yang sama PT Agung Podomoro Land (APLN) juga mengalami penurunan rating dari CCC+ menjadi CCC-. Selain ASRI dan APLN entitas property dan real estat yang turut mengalami penurunan rating yaitu PT PP Properti dari BBB+ menjadi BBB-. Beberapa penyebab turunnya rating perusahaan properti dan real estate dikarenakan perusahaan gagal membayar hutang, menurunnya tingkat penjualan, serta arus kas yang minim (http://market.bisnis.com, 2020).

Penggunaan hutang yang besar merupakan kesalahan dalam pemilihan struktur modal yang mengakibatkan peningkatan risiko kebangkrutan dan turunnya nilai perusahaan karena ketidakmampuan perusahaan dalam melunasi hutang beserta bunga atas hutang yang digunakan (Dewi dan Sudiartha, 2017). Struktur modal yang tepat akan membuat perusahaan terhindar dari risiko gagal bayar. Perusahaan dengan return on investment dan arus kas yang besar tidak akan kesulitan dalam membayar hutang beserta bunga dari hutang yang digunakan (Rustam, 2015). Bebeberapa perusahaan properti dan real estat mengajukan permohonan pailit dikarenakan gagal membayar hutang yang jatuh tempo di tahun 2020 diantaranya adalah PT Kota Satu Properti , PT Cowell Development, PT Armidian Karyatama dan PT Sentul City. (http://wartaekonomi.co.id, 2021)

Menurut Yohanes (2014) penggunaan pinjaman akan menimbulkan financial distress berupa biaya agensi dan biaya kebangkrutan. Semakin tinggi DER semakin besar juga risiko bisnis 
perusahaan. Apabila DER lebih dari satu artinya entitas lebih banyak menggunakan hutang daripada modal sendiri. Menurut Rustam (2015) alasan banyaknya penggunaan hutang daripada modal sendiri dikarenakan jumlah modal sendiri terbatas. Pemilihan struktur modal akan berpengaruh pada pendanaan kegiatan operasional perusahaan. Oleh karena itu, manajemen keuangan perusahaan perlu mempertimbangkan pemilihan struktur modal perusahaannya. Manajer harus mengetahui aspek-aspek yang mempengaruhi struktur pendanaan agar bisa menjadi dasar pertimbangan dalam pemilihan struktur modal entitas

Aspek-aspek yang memengaruhi struktur modal telah banyak dilakukan penelitian oleh peneliti sebelumnya. Dalam penelitian sebelumnya masih menunjukkan hasil yang belum konsisten mengenai pengaruh struktur aset, risiko bsnis dan pertumbuhan penjualan terhadap struktur modal. Research gap variabel struktur aset berdasarkan penelitian yang dilakukan oleh Srimindarti dan Hardiningsih (2015), Denziana dan Yunggo (2017), Nur'aini et al. (2020) memperoleh hasil bahwa struktur aset memiliki pengaruh positif terhadap struktur modal. Hal tersebut bertentangan dengan hasil observasi yang dilakukan oleh Yohanes (2014), Ridho (2019) dengan hasil bahwa struktur aset memiliki pengaruh negatif terhadap struktur modal. Sedangkan menurut Dara (2018) struktur aset tidak mempunyai pengaruh signifikan terhadap struktur modal.

Berdasarkan penelitian yang dilaksanakan oleh Fitriani et al. (2014) memperoleh hasil bahwa risiko bisnis memiliki pengaruh positif terhadap struktur modal. Hal ini menunjukkan hasil yang tidak sejalan pada observasi yang dilakukan oleh Buana dan Khafid (2018), Dewi dan Lestari (2014) dengan hasil bahwa risiko bisnis memiliki pengaruh negatif terhadap struktur modal perusahaan. Sedangkan Mufidah et al. (2018), Nur'aini et al. (2020) memperoleh hasil bahwa risiko bisnis tidak memiliki pengaruh terhadap struktur modal.

Hasil penelitian yang dilakukan Maryanti (2016) memperoleh hasil bahwa pertumbuhan penjualan tidak memiliki pengaruh yang signifikan terhadap struktur modal. Hal ini bertentangan pada observasi yang dilakukan Suweta dan Dewi (2016) yang memperoleh hasil bahwa sales growth memiliki pengaruh yang signifikan dan positif terhadap struktur modal. Sedangkan menurut hasil penelitian yang dilakukan Ridwan dan Diyani (2018) menunjukkan hasil bahwa pertumbuhan penjualan memiliki pengaruh negatif terhadap struktur modal.

Penelitian ini bertujuan untuk menganalisis dan mendeskripsikan pengaruh struktur aset, risiko bisnis dan pertumbuhan penjualan terhadap struktur modal dengan menggunakan profitabilitas sebagai variabel moderating pada perusahaan properti dan real estat yang terdaftar di BEI tahun 2017-2019. Profitabilitas digunakan sebagai variabel moderating karena berdasarkan hasil penelitian-penelitian sebelumnya profitabilitas memiliki hasil yang konsisten terhadap struktur modal. Penelitian ini didasarkan pada pecking order theory dan trade off theory.

\section{TINJAUAN LITERATUR DAN HIPOTESIS}

\section{Pecking Order Theory}

Pecking order theory pertamakali dikemukakan pada tahun 1961 oleh Donaldson, teori ini kemudian dikembangakan oleh Myers dan Maljuf di tahun 1984. Pecking order theory menguraikan mengenai tingkatan sumber pendanaan yang disukai. Teori pecking order mengklasifikasikan bahwa entitas mengutamakan penggunaan pendanaan internal seperti laba ditahan, apabila penggunaan laba ditahan belum mencukupi untuk kegiatan operasional entitas dapat menambah pendanaan dengan risiko yang lebih ringan seperti hutang dan apabila laba ditahan dan hutang belum mencukupi pendanaan kegiatan operasional perusahaan dapat menerbitkan saham sebagai pilihan terakhir (Insiroh 2014). Menurut Jusrizal (2017) teori pecking 
order menjelaskan bahwa entitas memanfaatkan hutang atau modal eksternal yang lebih sedikit apabila perusahaan memiliki profitabilitas tinggi.

\section{Trade Off Theory}

Struktur modal berdasarkan trade off theory atau balancing theory menjelaskan mengenai penggunaan hutang tidak hanya memiliki manfaat tetapi juga menimbulkan pengorbanan. Teori ini pertamakali dikemukakan Kraus dan Litzenberger (1973) yang menjelaskan mengenai penyeimbangan manfaat pajak dari bunga hutang terhadap biaya financial distress dan kebangkrutan. Menurut Sjahrial (2007) trade off theory menjelaskan apabila entitas semakin besar menggunakan hutang dalam pendanaannya maka makin tinggi pula keuntungan yang akan diperoleh. Tetapi penggunaan hutang yang besar juga akan meningkatkan biaya agensi dan financial distress. Menurut Srimindarti dan Hardiningsih (2015) tambahan hutang masih diperbolehkan jika perusahaan masih memiliki ketersediaan aset tetap yang digunakan untuk jaminan dan hutang tersebut memiliki manfaat yang jauh lebih besar dibandingkan dengan biayanya.

\section{Struktur Modal}

Menurut Sjahrial (2007) struktur modal ialah perbandingan antara penggunaan pendanaan yang diperoleh dari modal berupa pinjaman seperti pinjaman jangka pendek yang memiliki karakteristik tetap dan long term debt dibandingkan dengan sumber pendanaan internal seperti saham preferen dan saham biasa. Menurut Suwardjono (2005) sumber komponen modal terdiri atas lima sumber pendanaan. Pertama, pendanaan yang diperoleh dari setoran pemegang saham. Kedua, sisa laba setelah pembagian dividen berupa laba ditahan. Ketiga, pendanaan yang diperoleh akibat dari apresiasi/revaluasi aset tertentu. Keempat, sumbangan dari pihak non pemegang saham. Terakhir, pendanaan yang diperoleh dari sumber lainnya. Manajemen keuangan harus mampu memilih komposisi struktur pendanaan yang tepat demi tercapainya sasaran entitas. Dalam pemilihan komposisi modal yang tepat manajemen keuangan harus mempertimbangkan aspekaspek yang berpengaruh pada struktur modal. menurut Sulindawati et al. (2017) aspek-aspek yang harus dipertimbangkan dalam pemilihan struktur modal yaitu; going concern, pengawasan, asset structure, risiko bisnis, management conservatism, tingkat pertumbuhan, pajak, dan cadangan kemampuan peminjaman.

\section{Struktur Aset}

Menurut Yohanes (2014) struktur aset merupakan komposisi perimbangan antara aset tetap dan jumlah aset yang dimiliki oleh entitas. Menurut Ariyani et al. (2018) struktur aset merupakan seluruh total aset yang dipunyai perusahaan dalam menjalankan usahanya. Struktur aset digunakan perusahaan untuk menentukan seberapa besar komposisi penggunaan dana eksternal berupa hutang jangka panjang dalam struktur modalnya. Makin besar fixed asset yang dipunyai entitas maka makin besar pula hutang yang dapat diajukan perusahaan. Banyaknya aset tetap akan dijadikan dasar bagi kreditur untuk memberikan pinjaman

\section{Risiko Bisnis}

Risiko bisnis ialah suatu ketidakpastian atau kemungkinan yang tidak diinginkan oleh entitas. Risiko bisnis mencerminkan ketidakpastian tingkat penghasilan laba perusahaan dimasa depan (Cahyani dan Isbanah 2019). Menurut Dewi dan Lestari (2014) risiko bisnis muncul apabila entitas tidak mampu membiayai seluruh biaya operasionalnya. Risiko bisnis dapat muncul semakin 
besar jika perusahaan menggunakan hutang dalam jumlah yang besar. Semakin banyak struktur modal berupa pinjaman maka akan semakin besar biaya yang muncul atas hutang yang digunakan berupa biaya agensi dan financial distress.

\section{Pertumbuhan Penjualan}

Pertumbuhan penjualan merupakan peningkatan maupun penurunan penjualan dari tahun ke tahun yang disajikan dalam laporan laba rugi perusahaan (Maryanti 2016). Menurut Suweta dan Dewi (2016) pertumbuhan penjualan yang meningkat dan stabil akan berefek positif pada keuntungan perusahaan dan akan mempengaruhi keputusan pendanaan perusahaan. Entitas yang memiliki penjualan yang terus meningkat dan cenderung stabil akan dinilai lebih tahan risiko sehingga kreditur akan makin mudah memberikan pinjaman pada entitas

\section{Profitabilitas}

Menurut Husnan dan Pudjiastuti (2015) profitabilitas merupakan ukuran kemampuan entitas dalam menghasilkan keuntungan dari penjualan, dari aset- aset yang dimilikinya, maupun dari modal yang dimiliki perusahaan. Sedangkan menurut Jusrizal dan H (2017) profitabilitas ialah ukuran yang mencerminkan kemampuan entitas dalam memperoleh keuntungan dan gambaran kemampuan efektif atau tidaknya manajemen dalam mengelola operasi.

\section{Pengaruh Struktur Aset terhadap Struktur Modal}

Struktur aset merupakan perbandingan antara jmlah aset tetap dibandingkan dengan seluruh jumlah aset yang dimiliki perusahaan (Yohanes, 2014). Perusahaan yang memiliki aset tetap banyak akan lebih mudah memperoleh pinjaman dari kreditur. Aset tetap berupa tanah dan bangunan dapat digunakan sebagai jaminan hutang perusahaan. Hal ini sesuai dengan trade off theory yang menjelaskan mengenai tambahan hutang masih diperbolehkan sejauh memiliki masa manfaat yang lebih besar dan perusahaan memiliki aset tetap yang sebagai jaminan. Berdasarkan observasi yang dilakukan oleh Suweta dan Dewi (2016), memperoleh hasil bahwa struktur aset mempunyai pengaruh positif terhadap struktur modal. Hal ini sejalan dengan observasi yang dilakukan oleh Sahabuddin (2017), Srimindarti dan Hardiningsih (2015), Buana dan Khafid (2018), Muslimah et al. (2020) yang menyatakan bahwa semakin tinggi struktur aset perusahaan maka perusahaan akan meningkatkan penggunaan hutang sebagai modalnya. Berdasarkan hasil penelitian tersebut, maka dapat dirumuskan hipotesis sebagai berikut

\section{H1 : Struktur aset berpengaruh positif dan signifikan terhadap struktur modal Pengaruh Risiko Bisnis terhadap Struktur Modal}

Risiko bisnis merupakan suatu ketidakpastian yang dihindari oleh perusahaan. Risiko bisnis merupakan suatu kondisi dimana perusahaan tidak mampu membiayai kegiatan operasionalnya dikarenakan kurangnya pendanaan (Mufidah et al., 2018), Perusahaan dengan risiko bisnis yang tinggi sebaiknya mengurangi penggunaan hutangnya berlebih (Brigham dan Houston 2013). Hal ini sejalan dengan berdasarkan pecking order theory menyatakan perusahaan dengan risiko bisnis tinggi akan berusaha mengurangi pemakaian hutang dalam struktur modalnya. Semakin tinggi risiko bisnis perusahaan maka struktur modal entitas berupa hutang akan semakin rendah. Perusahaan dengan risiko bisnis tinggi yang tetap menggunakan hutang dalam jumlah yang besar akan dapat mengakibatkan perusahaan mengalami financial distress hingga kebangkrutan. Hal ini sejalan dengan hasil penelitian yang dilakukan oleh Buana dan Khafid (2018), Cahyani dan Isbanah (2019), Wardani dan Subowo (2020) yang memperoleh hasil bahwa risiko bisnis memiliki 
Jurnal Akuntansi Bisnis, Vol. 19, No. 1, Maret 2021

ISSN 1412-775X (media cetak) | 2541-5204 (media online)

pengaruh negatif terhadap struktur modal perusahaan. Berdasarkan hasil penelitian tersebut, maka dapat dirumuskan hipotesis sebagai berikut

\section{H2: Risiko bisnis berpengaruh negatif dan signifikan terhadap struktur modal Pengaruh Pertumbuhan Penjualan terhadap Struktur Modal}

Entitas yang sedang tumbuh akan membutuhkan pendanaan yang besar untuk kegiatan operasional dan investasinya. Perusahaan dengan tingkat pertumbuhan penjualan yang stabil akan mempunyai tingkat keuntungan penjualan yang pasti, sehingga perusahaan tidak mengalami kesulitan dalam membiayai beban operasionalnya. Semakin meningkatkan dan stabilnya tingkat penjualan perusahaan juga dapat memberikan sinyal kepada pihak eksternal jika perusahaan memiliki kinerja yang baik. Perusahaan dengan pertumbuhan penjualan yang stabil akan lebih mudah mendapatkan pendanaan berupa hutang dari kreditur. Penggunaan hutang akan memberikan manfaat berupa pengurangan pajak. Hal ini sesuai dengan teori trade off theory yang menjelaskan semakin tinggi tingkat penjualan maka akan semakin tinggi laba dan pajak yang dibayarkan perusahaan, sehingga perusahaan menggunakan lebih banyak hutang agar dapat mengurangi biaya pajak yang dibayar dan untuk menunjang kegiatan operasional dan investasinya. Hal ini berarti sales growth mempunyai pengaruh yang positif terhadap struktur modal. Hal ini selaras dengan penelitian yang dilakukan sebelumnya oleh Suweta dan Dewi (2016), Thalib et al. (2019) memperoleh hasil bahwa pertumbuhan penjualan memiliki pengaruh positif terhadap struktur modal perusahaan. Berdasarkan hasil penelitian tersebut, maka dapat dirumuskan hipotesis sebagai berikut:

\section{H3: Pertumbuhan penjualan berpengaruh positif dan signifikan terhadap struktur modal}

\section{Profitabilitas Memoderasi Hubungan Struktur Aset dan Struktur Modal}

Profitabilitas merupakan salah satu dasar perimbangan kreditor untuk memberikan pinjaman kepada perusahaan. Perusahaan yang mempunyai tingkat profitabilitas tinggi akan makin mudah mendapatkan kepercayaan akan pinjaman yang makin besar dibandingkan dengan entitas yang memiliki tingkat profitabilitas yang rendah. Hal ini sejalan dengan trade off theory yang menyatakan perusahaan dengan tingkat profitabilitas yang stabil akan lebih mudah mendapatkan pendanaan eksternal karena dianggap lebih tidak berisiko. Sehingga perusahaan yang memiliki profitabilitas tinggi akan dapat menggunakan lebih banyak hutang dalam struktur modalnya. Menurut trade off theory perusahaan akan menyesuaikan antara manfaat dan risiko dari penggunaan hutang. Perusahaan dapat menggunakan lebih banyak hutang jika penggunaan hutang memiliki manfaat yang lebih besar dari risiko yang ditimbulkan dan perusahaan memiliki persediaan aset tetap yang cukup sebagai jaminannya. Semakin tinggi struktur aset perusahaan maka semakin meningkat kepercayaan kreditur kepada perusahaan sehingga kreditur bersedia untuk meminjamkan hutang dalam jumlah yang besar. Aset tetap yang dijadikan agunan dapat diambil alih oleh pihak kreditur jika perusahaan tidak mampu membayar pinjamannya. Berdasarkan hasil penelitian tersebut, maka dapat dirumuskan hipotesis sebagai berikut:

\section{H4: Profitabilitas mampu memoderasi secara positif dan signifikan pengaruh struktur aset terhadap struktur modal}

\section{Profitabilitas Memoderasi Hubungan Risiko Bisnis terhadap Struktur Modal}

Profitabilitas merupakan salah satu dasar pertimbangan pihak eksternal dalam menilai perusahaan. Profitabilitas merupakan ukuran kemampuan perusahaan dalam memperoleh laba (Husnan dan Pudjiastuti, 2015). Entitas yang memiliki profitabilitas tinggi akan memiliki jumlah 
laba ditahan yang cukup untuk pendanaannya. Kondisi ini sejalan dengan teori pecking order yang menjelaskan bahwa jika entitas yang mempunyai profitabilitas tinggi akan mengutamakan penggunaan dana internalnya berupa laba ditahan dibandingkan dengan menggunakan pendanaan eksternal. Tinggi rendahnya risiko bisnis dapat memengaruhi struktur pendanaan entitas. Perusahaan dengan risiko bisnis tinggi lebih baik mengurangi hutang dalam struktur pendanaannya. Jika entitas yang mempunyai risiko bisnis tinggi tetap memaksimalkan penggunaan hutang maka akan dapat meningkatkan risiko menjadi lebih tinggi hingga berakibat pada kebangkrutan. Perusahaan dengan risiko tinggi akan sulit mengembalikan pinjaman serta bunga atas pinjamannya, hal inilah yang dapat mengakibatkan semakin meningkatnya risiko bisnis. Entitas yang memiliki profitabilitas tinggi akan memiliki jumlah laba ditahan yang cukup untuk pendanaannya sehingga perusahaan akan menggunakan lebih sedikit hutang dalam struktur modalnya untuk mengindari makin tingginya risiko bisnis. Berdasarkan hasil penelitian tersebut, maka dapat dirumuskan hipotesis sebagai berikut:

\section{H5: Profitabilitas mampu memoderasi secara negatif dan signifikan pengaruh risiko bisnis terdahadap struktur modal}

\section{Profitabilitas Memoderasi hubungan Pertumbuhan Penjualan dan Struktur Modal}

Profitabilitas menunjukkan tingkat kemampuan entitas untuk mendapatkan laba. Semakin tinggi profitabilitas maka semakin mudah entitas mendapatkan kepercayaan kreditor untuk menyerahkan pinjaman. Sesuai dengan trade off theory perusahaan yang memiliki profitabilitas tinggi dapat menggunakan lebih banyak hutang dalam struktur modalnya. Semakin tingginya laba akan membuat pajak yang dibayarkan perusahaan juga semakin tinggi. Sehingga perusahaan akan menggunakan lebih banyak hutang dikarenakan penggunaan hutang akan memberikan manfaat berupa pengurangan pajak yang dibayarkan perusahaan. Pertumbuhan penjualan yang tinggi membutuhkan pendanaan yang besar untuk kegiatan operasional dan investasi perusahaan. Kebutuhan modal yang meningkat akan mendorong perusahaan menggunakan pendanaan eksternal jika pendanaan internalnya tidak mencukupi. Perusahaan yang memiliki pertumbuhan penjualan yang stabil akan membuat pihak eksternal semakin yakin untuk memberikan pinjaman atau menanamkan modalnya di perusahaan. Berdasarkan hasil penelitian tersebut, maka dapat dirumuskan hipotesis sebagai berikut:

\section{H6: Profitabilitas mampu memoderasi secara positif dan signifikan pengaruh pertumbuhan penjualan terhadap struktur modal}

\section{METODE PENELITIAN}

\section{Populasi dan Sampel}

Penelitian ini berupa penelitian kuantitatif. Data yang digunakan dalam penelitian berupa data sekunder. Populasi yang diamati dalam penelitian ini adalah seluruh perusahaan properti dan real estat yang terdaftar di Bursa Efek Indonesia tahun 2017-2019 sejumlah 78 perusahaan. Teknik pengambilan data yang digunakan dalam penelitian ini berupa metode dokumentasi yang berupa data dokumentasi laporan keuangan perusahaan properti dan real estat yang terdaftar di Bursa Efek Indonesia tahun 2017-2019. Metode pengambilan sampel yang digunakan adalah metode purposive sampling. Perusahaan yang termasuk dalam sampel adalah perusahaan menerbitkan laporan keuangan secara berturut-turut selama periode penelitian, memiliki aset tetap, dan 
Jurnal Akuntansi Bisnis, Vol. 19, No. 1, Maret 2021 ISSN 1412-775X (media cetak) | 2541-5204 (media online)

melakukan penjualan secara berturut-turut selama periode penelitian. Tabel 1 menyajikan secara detail seleksi pemilihan sampel. Berdasarkan kriteria-kriteria yang telah ditetapkan, sampel yang diperoleh sebanyak 49 perusahaan dengan 147 observasi selama tiga tahun.

\section{Tabel 1. Prosedur Pemilihan Sampel}

\begin{tabular}{llcc}
\hline No & \multicolumn{1}{c}{ Kriteria } & Tidak Masuk Kriteria & Masuk Kriteria \\
\hline 1 & $\begin{array}{l}\text { Perusahaan yang secara terus-menerus } \\
\text { menerbitkan laporan keuangan yang lengkap } \\
\text { melalui laman resmi Bursa Efek Indonesia } \\
\text { (BEI) mulai periode tahun 2017-2019 }\end{array}$ & $(22)$ & 56 \\
2 & $\begin{array}{l}\text { Perusahaan yang memiliki persediaan aset } \\
\text { tetap dari tahun 2017-2019 }\end{array}$ & $(2)$ & 54 \\
3 & $\begin{array}{l}\text { Perusahaan yang secara terus menerus } \\
\text { melakukan penjualan dari tahun 2017-2019 }\end{array}$ & $(5)$ & 49 \\
& $\begin{array}{l}\text { Jumlah perusahaan } \\
\text { Tahun pengamatan }\end{array}$ & & 49 \\
\hline & Unit analisis & & 3 \\
\hline
\end{tabular}

Sumber : Data sekunder yang diolah, 2021

\section{Definisi dan Pengukuran Variabel}

Tabel 2 menyajikan definisi dan pengukuran variabel serta referensi yang digunakan berdasarkan penelitian terdahulu yang dijadikan acuan.

\section{Tabel 2. Definisi Operasional Variabel}

\begin{tabular}{|c|c|c|c|}
\hline $\begin{array}{l}\text { Nama } \\
\text { Variabel }\end{array}$ & Definisi & Pengukuran & Referensi \\
\hline Struktur Modal & $\begin{array}{c}\text { arbandingan antara modal asing dengan } \\
\text { modal sendiri }\end{array}$ & $\begin{array}{c}\text { DER }=\text { Total Hutang }: \text { Total } \\
\text { Modal }\end{array}$ & $\begin{array}{l}\text { Nur'aini et al. } \\
\text { 2020) }\end{array}$ \\
\hline Struktur Asset & $\begin{array}{l}\text { Komposisi perbandingan aset tetap dan } \\
\text { jumlah aset milik entitas }\end{array}$ & AS =Total Aset Tetap : Total Aset & Yohanes, 2014) \\
\hline Risiko Bisnis & $\begin{array}{l}\text { Ketidakmampuan entitas dalam } \\
\text { membiayai kegiatan operasionalnya }\end{array}$ & Brisk $=$ EBIT $:$ Total Aset & $\begin{array}{l}\text { Nur'aini et al. } \\
\text { 2020) }\end{array}$ \\
\hline $\begin{array}{r}\text { Pertumbuhan } \\
\text { Penjualan }\end{array}$ & $\begin{array}{c}\text { Peningkatan atau penurunan penjualan } \\
\text { dari satu periode ke periode } \\
\text { selanjutnya }\end{array}$ & $\begin{array}{l}\left.\mathrm{G}=\left(\text { Penjualan }_{\mathrm{t}}-\text { Penjualan } \mathrm{t}-1\right)\right) \\
\text { 'enjualan } \mathrm{t}-1\end{array}$ & Maryanti 2016) \\
\hline $\begin{array}{l}\text { Variabel } \\
\text { Moderating } \\
\text { Profitabilitas }\end{array}$ & $\begin{array}{c}\text { Kemampuan perusahaan menghasilkan } \\
\text { laba dari penjulannya, dari aset- aset } \\
\text { yang dimilikinya, maupaun dari } \\
\text { ekuitas yang dimiliki perusahaan }\end{array}$ & ROA $=$ Laba Bersih $:$ Total Aset & $\begin{array}{l}\text { Nur'aini et al. } \\
\text { 2020) }\end{array}$ \\
\hline
\end{tabular}

Sumber: Berbagai sumber diolah, 2021

Teknik pengambilan data menggunakan metode dokumentasi dari laporan keuangan perusahaan sampel. Alat analisis data yang digunakan adalah IBM SPSS Statistics 23. Penelitian 
Jurnal Akuntansi Bisnis, Vol. 19, No. 1, Maret 2021 ISSN 1412-775X (media cetak) | 2541-5204 (media online)

ini dianalisis menggunakan teknik analisis statistika deskriptif dan analisis statistika inferensial dengan Moderated Regresion Analysis (MRA). Teknik statistik deskriptif dalam penelitian ini digambarkan melalui nilai terendah, nilai tertinggi, standar deviasi dan nilai rata-rata yang disajikan dalam Error! Reference source not found.. Teknik analisis yang dimanfaatkan dalam penelitian ini adalah metode regresi linear berganda (MRA). Penelitian ini menggunakan model regresi dengan rumus sebagai berikut:

$$
\mathrm{DER}=\alpha+\beta_{1} \mathrm{AS}+\beta_{2} \mathrm{BRISK}+\beta_{3} \mathrm{SG}+\beta_{4} \mathrm{AS} * \mathrm{ROA}+\beta_{5} \mathrm{BRISK} * \mathrm{ROA}+\beta_{6} \mathrm{SG} * \mathrm{ROA}+\mathrm{e}
$$

\section{HASIL DAN PEMBAHASAN}

Statistika deskriptif dalam penelitian ini digambarkan melalui nilai maksimum, nilai minimum, nilai rata-rata dan standar deviasi. Hasil analisis statistika deskriptif disajikan dalam tabel sebagai berikut:

Tabel 3. Statistik Deskriptif

\begin{tabular}{lcrrrr}
\hline & $\mathrm{N}$ & \multicolumn{1}{c}{ Minimum } & Maksimum & Rata-Rata & Std. Deviation \\
\hline DER & 147 &, 05550 & 9,94337 &, 9568718 & 1,23313101 \\
AS & 147 &, 00017 &, 61613 &, 0854485 &, 12020004 \\
BRISK & 147 &,- 08057 &, 65024 &, 0417876 &, 06795124 \\
SG & 147 &,- 91230 & 1,53341 &, 0040146 &, 33654305 \\
ROA & 147 &,- 20898 &, 60593 &, 0293727 &, 07561952 \\
\hline
\end{tabular}

Sumber: Output SPSS 23, 2021

Tabel 3 menunjukkan perusahaan perusahaan yang memiliki nilai maksimum struktur modal (DER) sebesar 9,94337 dimiliki oleh PT Pollux Investasi Internasional Tbk (POLI) pada tahun 2019. Kondisi ini mengisyaratkan PT Pollux Investasi Internasional Tbk lebih banyak memakai sumber pendanaan eksternal berupa hutang untuk struktur modalnya dibandingkan pendanaan internalnya karena memiliki DER yang besarnya lebih dari 1. Nilai maksimum struktur aset (AS) sebesar 0, 61613 dimiliki oleh PT Duta Anggada Realty Tbk (DART) pada tahun 2017. Hal ini berari PT Duta Anggada Realty Tbk memiliki jumlah aset tetap yang lebih banyak dalam struktur asetnya. Nilai maksimum risiko bisnis (BRISK) sebesar 0,65024 adalah PT Bima Sakti Pertiwi Tbk (PAMG) pada tahun 2018. Nilai tertinggi pertumbuhan penjualan (SG) sebesar 1,53341 adalah PT Bhuwanatala Indah Permai Tbk (BIPP) pada tahun 2019. Hal ini berarti BIPP mengalami kenaikan penjualan dari tahun 2018 sebesar Rp 130.613.332.148 menjadi Rp 330.897.278.808 pada tahun 2019. Nilai maksimum profitabilitas (ROA) sebesar 0,60593 adalah PT Bima Sakti Pertiwi Tbk (PAMG) pada tahun 2018 dengan jumlah laba bersih setelah pajak Rp 318.580.786.910 dibandingkan dengan jumlah total aset saat itu sebesar Rp 525.775.134.369.

Sebelum melakukan pengujian hipotesis data dalam penelitian telah diuji dengan uji asumsi klasik. Namun dalam uji asumsi klasik menunjukkan masalah normalitas data sehingga dilakukan tindakan korektif berupa tindakan tranformasi data ke dalam fungsi LN (logaritma natural). Uji asumsi klasik yang digunakan dalam penelitian ini melupiti uji normalitas, uji heteroskedastisitas, 
uji autokorelasi, dan uji multikolinearitas. Setelah dilakukan uji asumsi klasik selanjutnya dilakukan pengujian hipotesis penelitian.

Hasil uji koefisien determinasi dalam kolom Adjusted $R$ Square sebesar 0,105. Hal ini berarti variabel independen yang digunakan berupa struktur aset, risiko bisnis, pertumbuhan penjualan dan profitabilitas sebagai variabel moderasi dapat mendeskripsikan variabel struktur modal sebesar $10,5 \%$. Sedangkan sisanya sebesar $89,5 \%$ faktor-faktor yang mempengaruhi struktur modal dijelaskan oleh variabel lain yang tidak digunakan dalam penelitian ini. Hasil pengujian hipotesis dapat dilihat pada Tabel 4 berikut ini:

Tabel 4. Hasil Uji Hipotesis

\begin{tabular}{|c|l|l|l|l|l|}
\hline & \multicolumn{1}{|c|}{$\begin{array}{l}\text { Koefisien } \\
\text { Regresi }\end{array}$} & Sig. & Alpha & Keputusan \\
\hline H1 & $\begin{array}{l}\text { Struktur aset berpengaruh positif dan } \\
\text { signifikan terhadap struktur modal }\end{array}$ & 0,499 & 0,008 & 0,05 & Diterima \\
\hline H2 & $\begin{array}{l}\text { Risiko bisnis berpengaruh negatif dan } \\
\text { signifikan terhadap struktur modal }\end{array}$ & $-0,192$ & 0,455 & 0,05 & Ditolak \\
\hline H3 & $\begin{array}{l}\text { Pertumbuhan penjualan berpengaruh positif } \\
\text { dan signifikan terhadap struktur modal }\end{array}$ & $-2,181$ & 0,052 & 0,05 & Ditolak \\
\hline H4 & $\begin{array}{l}\text { Profitabilitas mampu memoderasi secara } \\
\text { positif dan signifikan pengaruh struktur aset } \\
\text { terhadap struktur modal }\end{array}$ & 0,109 & 0,022 & 0,05 & Diterima \\
\hline H5 & $\begin{array}{l}\text { Profitabilitas mampu memoderasi secara } \\
\text { negatif dan signifikan pengaruh risiko } \\
\text { bisnis terhadap struktur modal }\end{array}$ & $-0,127$ & 0,040 & 0,05 & Diterima \\
\hline H6 & $\begin{array}{l}\text { Profitabilitas mampu memoderasi secara } \\
\text { positif dan signifikan pengaruh } \\
\text { pertumbuhan penjualan terhadap struktur } \\
\text { modal }\end{array}$ & $-0,354$ & 0,139 & 0,05 & Ditolak \\
\hline
\end{tabular}

Sumber : data diolah SPPSS 23, 2021

\section{Pengaruh Struktur Aset terhadap Struktur Modal}

Hasil dari penelitian ini membuktikan bahwa struktur aset memiliki pengaruh positif dan signifikan terhadap struktur modal. Hal ini selaras dengan trade off theory yang menyebutkan bahwa perusahaan dapat menggunakan lebih banyak hutang apabila hutang tersebut memiliki masa manfaat yang lebih besar dibandingkan dengan risikonya dan penambahan hutang masih diperbolehkan jika perusahaan memiliki jumlah aset tetap yang cukup untuk jaminan hutangnya. Semakin besar struktur aset perusahaan akan membuat kreditur semakin percaya untuk memberikan pinjaman berupa hutang.

Menurut Srimindarti dan Hardiningsih (2015) perusahaan yang memiliki struktur aset yang besar akan makin banyak menggunakan pinjaman dalam struktur modalnya dibandingkan dengan sumber pendanaan internal. Struktur aset yang besar akan mendorong perusahaan untuk meningkatkan keuntungan dari penggunaan hutang semaksimal mungkin. Hal berarti peningkatan penggunaan hutang akan dapat meningkatkan kapasitas produksi yang dapat meningkatkan 
penjualan perusahaan, peningkatan penjualan tentunya akan meningkatkan laba perusahaan. Menurut Buana dan Khafid (2018) meningkatnya laba perusahaan akan membuat perusahaan memiliki pajak yang tinggi. Perusahaan akan menggunakan hutang karena hutang memiliki manfaat sebagai pengurang biaya pajak yang dibayarkan perusahaan.

Hal ini berarti manajemen perusahaan mempertimbangkan banyaknya struktur aset yang dimiliki perusahaan sebelum mengambil keputusan struktur modalnya Semakin tingginya struktur aset yang dimiliki perusahaan maka semakin banyak hutang yang digunakan oleh perusahaan. Hasil penelitian ini tidak selaras dengan penelitian sebelumnya yang dilakukan oleh Denziana dan Yunggo (2017), Ridwan dan Diyani (2018), Muslimah, Suhendro dan Masitoh (2020) yang menyatakan bahwa terdapat hubungan negatif dan signifikan antara struktur aset terhadap struktur modal serta penelitian yang dilakukan oleh Maryanti (2016), Ariyani et al. (2018), dan Indah et al. (2018) yang menyatakan bahwa tidak terdapat hubungan yang signifikan antara struktur aset dengan struktur modal. Namun hasil dari penelitian ini sejalan dengan penelitian yang dilakukan oleh Srimindarti dan Hardiningsih (2015), Matias dan Serrasqueiro (2016), Suweta dan Dewi (2016), Sahabuddin (2017), Buana dan Khafid (2018), Dewiningrat dan Mustanda (2018), Chandra, Ng dan Chandra (2020) yang memperoleh hasil bahwa struktur aset memiliki pengaruh yang positif dan signifikan terhadap struktur modal.

\section{Pengaruh Risiko Bisnis terhadap Struktur Modal}

Hasil dari penelitian ini menunjukkan bahwa risiko bisnis tidak memiliki pengaruh yang negatif dan signifikan terhadap struktur modal. Hasil penelitian ini bertentangan dengan teori pecking order entitas dengan risiko bisnis yang cukup besar akan berusaha untuk meminimalisir penggunaan pendanaan eksternal berupa hutang dalam struktur modalnya. Menurut Buana dan Khafid (2018) semakin besar penggunaan hutang akan meningkatkan beban bunga atas hutang yang digunakan sehingga mengakibatkan risiko yang ditanggung perusahaan juga semakin tinggi. Perusahaan yang memiliki risiko bisnis yang tinggi akan mengurangi penggunaan hutang agar risiko yang ditanggung tidak semakin tinggi. Hasil penelitian ini juga tidak sejalan dengan trade off theory yang menyatakan perusahaan dapat menggunakan hutang jika memiliki manfaat yang lebih banyak dari risiko atas penggunaan hutang. Menurut Yohanes (2014) perusahaan yang memiliki hutang tinggi kemungkinan akan menggunakan hutang yang lebih banyak. Tingginya tingkat risiko akan membuat investor yang menyukai risiko tinggi akan menanamkan modalnya dengan anggapan risiko tinggi akan mendapat return yang tinggi.

Beberapa perusahaan properti dan real estat yang memiliki risiko bisnis tinggi justru memiliki komposisi struktur modal tinggi. Sebagai contoh adalah PT Marga Abhinaya Abadi Tbk mengalami kerugian sehingga risiko bisnisnya bernilai negatif dari tahun 2017-2019 tetapi perusahaan ini memiliki DER yang tinggi hingga lebih dari satu setiap tahunnya. Selain itu hal ini terjadi juga pada dan PT Cahayasakti Investindo Sukses Tbk, perusahaan ini memiliki risiko bisnis yang makin naik dari tahun 2017 hingga 2019 namun perusahaan ini justru makin meningkatkan hutang dalam struktur modalnya dari tahun ke tahun. Hal ini menunjukkan bahwa kreditur tidak terlalu memperhatikan risiko bisnis dalam pengambilan keputusan peminjaman dananya karena masih terdapat faktor lain yang lebih berpengaruh. Sehingga perusahaan masih mendapatkan kepercayaan dari kreditur untuk mengajukan pinjaman berupa hutang. Menurut Hartati dan Mukhibad (2018) risiko bisnis memiliki sifat yang tidak pasti sehingga tingkat risiko bisnis sulit untuk dijadikan ukuran dan dasar dalam pengambilan struktur modal perusahaan. Menurut Abdillah et al., (2018) manajer tidak terlalu memperhatikan faktor risiko bisnis dalam 
pengambilan keputusan struktur modalnya karena terdapat faktor lain yang lebih berpengaruh.

Hasil penelitian ini selaras dengan penelitian yang dilakukan oleh Hartati dan Mukhibad (2018), Mufidah, Ulupui dan Prihatni, (2018), Sutarka dan Hanafi (2018), Ridho (2019) yang memperoleh hasil bahwa risiko bisnis tidak memiliki pengaruh yang signifikan terhadap struktur modal. Namun tidak mendukung hasil dari penelitian yang dilakukan oleh Buana dan Khafid (2018), Cahyani dan Isbanah (2019), Wardani dan Subowo (2020) dengan hasil yang menunjukkan bahwa risiko bisnis memiliki pengaruh yang negatif dan signifikan terhadap struktur modal serta penelitian yang dilakukan oleh Fitriani, Mardi dan Indriani (2014), Sari (2016) dan Almanaseer (2019) dengan hasil bahwa risiko bisnis memiliki pengaruh positif dan signifikan terhadap struktur modal.

\section{Pengaruh Pertumbuhan Penjualan terhadap Struktur Modal}

Hasil dari penelitian ini menunjukkan bahwa pertumbuhan penjualan tidak memiliki pengaruh yang positif dan signifikan terhadap struktur modal. Sehingga temuan dalam penelitian ini tidak membuktikan penerapan dari trade off theory. Menurut trade off theory perusahaan yang mengalami pertumbuhan penjualan akan memiliki jumlah laba yang tinggi, jumlah laba yang tinggi akan dapat menaikkan pajak yang harus dibayar perusahaan. Sehingga menurut teori trade off perusahaan yang memiliki pertumbuhan penjualan yang tinggi akan menggunakan hutang untuk menurunkan pajak yang dibayarkan perusahaan. Manajemen keuangan akan mempertimbangkan kondisi perusahaan dan kemungkinan risiko yang mungkin dihadapi perusahaan jika menggunakan hutang. Hasil dari penelitian ini juga tidak mendukung pecking order theory yang menyatakan perusahaan yang mengalami pertumbuhan penjualan tinggi akan mengutamakan menggunakan pendanaan internal. Semakin tinggi tingkat pertumbuhan penjualan maka akan semakin banyak laba yang akan diperoleh perusahaan. Perusahaan memiliki jumlah pendanaan internal berupa laba ditahan yang dapat membiayai kegiatan operasional perusahaan.

Berdasarkan hasil dari penelitian ini sales growth tidak mempengaruhi keputusan struktur modal yang dipilih perusahaan. Hal ini dikarenakan penjualan perusahaan tidak selalu mengalami peningkatan dan cenderung bersifat fluktuatif. Sebagai contoh pada PT Sentul City Tbk (BKSL) penjualan properti dan real estat pada tahun 2017 sebesar Rp. 1.623.484.966.262 dan pada tahun 2018 sebesar Rp. 1.316.805.554.419 sedangkan pada tahun 2019 sebesar Rp. 951.421.027.715. Menurut Hartati dan Mukhibad (2018) pertumbuhan penjualan tidak bisa dijadikan penentu dalam pengambilan struktur modal perusahaan dikarenakan sifatnya yang tidak pasti.

Hasil penelitian ini mendukung hasil penelitian yang dilaksanakan oleh Maryanti (2016), Andayani dan Suardana (2018), serta Thalib, Herdiyana dan Wahid (2019) dengan hasil bahwa pertumbuhan penjualan tidak memiliki pengaruh signifikan terhadap struktur modal. Namun tidak mendukung hasil penelitian yang dilakukan oleh Dewiningrat dan Mustanda (2018) dengan hasil bahwa pertumbuhan penjualan berpengaruh negatif dan signifikan terhadap struktur modal serta penelitian yang dilakukan oleh Suweta dan Dewi (2016) yang memperoleh hasil bahwa pertumbuhan penjualan memiliki pengaruh positif dan signifikan terhadap struktur modal.

\section{Profitabilitas Memoderasi Pengaruh Struktur Aset terhadap Struktur Modal}

Hasil dari penelitian ini menunjukkan bahwa profitabilitas mampu memoderasi secara positif dan signifikan pengaruh struktur aset terhadap struktur modal. Hasil penelitian ini mendukung teori trade off yang menyatakan semakin tingginya profitabilitas suatu perusahaan akan dapat menaikkan tingkat penggunaan hutang dalam struktur modal perusahaan. Perusahaan 
yang memiliki struktur aset dan profitabilitas yang besar akan dapat menggunakan hutang dalam jumlah besar.

Perusahaan yang memiliki profitabilitas yang tinggi akan lebih mudah mendapatkan pinjaman berupa hutang dari pihak eksternal. Hal ini dikarenakan semakin besar struktur aset maka kreditur akan merasa lebih terjamin memberikan pinjaman pada perusahaan yang memiliki struktur aset tinggi. Kreditur dapat mengambil alih kepemilikan aset yang digunakan sebagai jaminan ketika perusahaan tidak mampu membayar hutang. Tingkat profitabilitas tinggi akan mempermudah perusahaan dalam melakukan pengajuan hutangnya. Kreditur akan lebih percaya pada perusahaan yang memiliki profitabilitas tinggi dikarenakan semakin tinggi profitabilitas maka perusahaan akan lebih mudah melunasi hutang beserta bunga atas hutang yang digunakan. Sebagian besar perusahaan properti dan real estat yang terdaftar di BEI memiliki profitabilitas tinggi dan struktur aset yang tinggi akan memiliki jumlah hutang yang tingginya lebih dari 50\% seperti PT Alam Sutera Realty, PT Agung Podomoro Land, PT Bumi Citra Permai, PT Sentul City, PT Ciputra Development, PT Diamond Citra Properti, dan PT Duta Anggada Realty.

Perusahaan yang ingin meningkatkan penjualannya memerlukan persediaan aset tetap yang memadai untuk menunjang kegiatan operasionalnya. Untuk memenuhi kebutuhan tersebut tentunya perusahaan memerlukan banyak tambahan dana seperti hutang agar mampu menunjang kegiatan operasional dan memaksimalkan keuntungan. Perusahaan akan mempertimbangkan manfaat pengurangan pajak dan kerugian berupa pembayaran beban bunga dari penggunaan hutang. Perusahaan akan menggunakan hutang jika hutang memiliki manfaat yang lebih besar dibandingkan dengan kerugian akibat beban yang ditimbulkan akibat penggunaan hutang (Buana dan Khafid 2018). Hasil penelitian ini sejalan dengan penelitian yang dilakukan oleh Chandra, $\mathrm{Ng}$ dan Chandra (2020), Kur dan Agbo (2021), serta Rakshit (2021) dengan hasil profitabilitas memiliki pengaruh signifikan terhadap struktur modal. Dapat disimpulkan bahwa profitabilitas mampu memoderasi secara positif dan signifikan pengaruh struktur aset terhadap struktur modal.

\section{Profitabilitas Memoderasi Pengaruh Risiko Bisnis terhadap Struktur Modal}

Hasil dari penelitian ini menunjukkan bahwa profitabilitas mampu memoderasi secara negatif dan signifikan pengaruh risiko bisnis terhadap struktur modal. Hasil dari penelitian ini sesuai dengan pecking order theory yang menyatakan perusahaan akan lebih mengutamakan pendanaan internal terlebih dahulu dibandingkan dengan menggunakan pendanaan eksternal. Hal ini dikarenakan makin banyaknya hutang akan memperbesar risiko bisnis perusahaan. Tinggi rendahnya profitabilitas akan dapat mempengaruhi keputusan struktur modal perusahaan.

Perusahaan properti dan real estat yang memiliki jumlah profitabilitas menurun akan menurunkan rasio penggunaan hutang dalam struktur modalnya. Hal ini dilakukan oleh manajemen perusahaan untuk menghindari makin tingginya risiko bisnis perusahaan. Sebagian besar perusahaan properti dan real estat seperti PT Agung Podomoro Land, PT Alam Sutera Realty, PT Bumi Citra Permai, PT Natura City Developments, PT Ciputra Development, dan PT Pakuwon Jati memilih untuk menurunkan rasio hutang dalam struktur modalnya untuk menghindari makin tingginya risiko bisnis. Hal ini dikarenakan perusahaan-perusahaan tersebut mengalami penurunan profitabilitas, jika profitabilitasnya turun dan perusahaan tetap menambahkan hutang dalam struktur modalnya maka perusahaan akan memiliki risiko yang tinggi hingga kebangkrutan.

Penggunaan hutang akan dapat meningkatkan risiko bisnis perusahaan. Semakin tinggi risiko perusahaan akan mengakibatkan perusahaan mengalami financial distress hingga 
Jurnal Akuntansi Bisnis, Vol. 19, No. 1, Maret 2021

ISSN 1412-775X (media cetak) | 2541-5204 (media online)

kebangkrutan. Hasil dari penelitian ini mendukung hasil dari penelitian yang dilakukan oleh Chandra, Ng dan Chandra (2020), Kur dan Agbo (2021), serta Rakshit (2021) dengan hasil profitabilitas memiliki pengaruh signifikan terhadap struktur modal. Dapat disimpulkan bahwa profitabilitas mampu memoderasi secara negatif dan signifikan pengaruh risiko bisnis terhadap struktur modal.

\section{Profitabilitas Memoderasi Pengaruh Pertumbuhan Penjualan terhadap Struktur Modal}

Hasil dari penelitian ini menunjukkan bahwa profitabilitas tidak mampu memoderasi secara positif dan signifikan pengaruh pertumbuhan penjualan terhadap struktur modal. Hasil dari penelitian ini tidak mendukung trade off theory yang menjelaskan jika perusahaan dengan profitabilitas serta pertumbuhan penjualan yang tinggi dapat menggunakan lebih banyak hutang. Perusahaan belum tentu akan menggunakan lebih banyak hutang untuk mengurangi biaya pajak yang dibayarkan dan membiayai kegiatan investasinya. Hal ini dikarenakan penjualan perusahaan bersifat tidak tetap dan fluktuatif. Manajemen tidak terlalu memperhatikan banyaknya pertumbuhan penjualan dalam penggunaan hutangnya. Hasil dari penelitian ini juga tidak mendukung pecking order theory yang menyatakan perusahaan dengan tingkat profitabilitas tinggi akan menggunakan pendanaa internal terlebih dahulu.

Beberapa perusahaan properti dan real estat tahun 2017-2019 yang mengalami penurunan profitabilitas dan penurunan tingkat pertumbuhan penjualan justru menambahkan penggunaan hutang dalam struktur modalnya seperti PT Binakarya Jaya Abadi, PT Bukit Darmo Property, PT Sentul City, PT Cahayasakti Investindo Sukses, PT Diamond Citra Properti, PT Megapolitan Developments, dan PT Fortune Mate Indonesia. Temuan penelitian ini membuktikan bahwa besarnya tingkat profitabilitas dan pertumbuhan penjualan tidak dapat dijadikan sebagai dasar oleh menajemen untuk mengambil keputusan struktur modalnya. Hal ini tidak sesuai dengan hasil penelitian yang dilakukan oleh Chandra, Ng dan Chandra (2020), Kur dan Agbo (2021), serta Rakshit (2021) dengan hasil profitabilitas memiliki pengaruh signifikan terhadap struktur modal. Dapat disimpulkan bahwa profitabilitas tidak mampu memoderasi secara positif dan signifikan pengaruh pertumbuhan penjualan terhadap struktur modal.

\section{SIMPULAN DAN SARAN}

Kesimpulan hasil penelitian ini dari enam hipotesis ada tiga hipotesis yang diterima yaitu struktur aset, profitabilitas mampu memoderasi struktur aset, profitabilitas mampu memoderasi pengaruh risiko bisnis. Dari hasil penelitian ini dapat diketahui bahwa nilai koefisien determinasi sejumlah $10,5 \%$ sehingga masih terdapat $89,5 \%$ faktor-faktor lain yang dapat mempengaruhi struktur modal yang tidak digunakan dalam penelitian ini. Objek penelitian yang digunakan dalam penelitian ini terbatas hanya pada perusahaan sektor properti dan real estat sajaBagi penelitian selanjutnya diharapkan menggunakan proksi atau faktor-faktor lain yang diduga dapat mempengaruhi struktur modal seperti yang dikemukakan oleh Brigham dan Houston (2013) diantaranya fleksibilitas keuangan, kondisi internal perusahaan, pajak, kondisi pasar, sikap pemberi pinjaman, dan leverage operasi. Diharapkan peneliti selanjutnya melakukan pengujian ulang terhadap faktor-faktor yang dapat mempengaruhi struktur modal pada perusahaan sektor lain sehingga dapat diketahui pengaruh struktur aset, risiko bisnis dan pertumbuhan penjualan apakah masih memiliki pengaruh yang konsisten terhadap struktur modal jika menggunakan objek selain perusahaan properti dan real estat seperti perusahaan sektor industri, infrastruktur, keuangan, teknologi dan sektor lainnya. 
Jurnal Akuntansi Bisnis, Vol. 19, No. 1, Maret 2021 ISSN 1412-775X (media cetak) | 2541-5204 (media online)

\section{DAFTAR PUSTAKA}

Abdillah, AN, Ikhsan, S, I, dan Mutia. 2018. Factors Affecting Capital Structure of Go Public Manufacturing Companies in BEI ( Indonesia Stock Exchange ) International Journal of. International Journal of Accounting Research 6(1):1-4. doi: 10.4172/2472-114X.1000173.

Almanaseer, S. Radwan. 2019. Determinants of Capital Structure: Evidence from Jordan. Accounting and Finance Research 8(4):186-98. doi: 10.5430/afr.v8n4p186.

Andayani, I. A. K. Trisia, dan K. A. Suardana. 2018. Pengaruh Profitabilitas, Likuiditas, Pertumbuhan Penjualan, dan Struktur Aktiva Pada Struktur Modal. Jurnal Akuntansi 24:370-98.

Ariani, N. K. A. dan N. L. P. Wiagustini. 2017. Faktor-Faktor Yang Mempengaruhi Struktur Modal Perusahaan Property \& Real Estate Yang Terdaftar Di BEI. Jurnal Manajemen 6(6):3168-95.

Ariyani, H. F. , I. Rini, D. Pangestuti, dan S. T. Raharjo. 2018. The Effect Of Asset Structure, Profitability, Company Size, and Company Growth in Capital Structure ( The Study of Manufacturing Companies Listed on the IDX for the Period 2013 - 2017 ). Jurnal Bisnis Strategi 27(2):123-36.

Brigham, E. F. dan J. F. Houston. 2013. Dasar-Dasar Manajemen Keuangan. 11 Buku 2. Jakarta: Salemba Empat.

Buana, F. K. dan M. Khafid. 2018. The Effect of Asset Structure and Business Risk on Capital Structure with Profitability as the Moderating Variable. Accounting Analysis Journal 7(3):200-206. doi: 10.15294/aaj.v7i3.22727.

Cahyani, I. D. dan Y. Isbanah. 2019. Pengaruh Struktur Kepemilikan, Tangibility, Firm Age, Business Risk, Kebijakan Dividen, dan Sales Growth terhadap Struktur Modal Sektor Properti Real Estate yang terdaftar di BEI periode 2012-2016. Jurnal Ilmu Manajemen $7: 124-32$.

Chandra, T., M. Ng. dan S. Chandra. 2020. The determinants of capital structure and stock returns ( The kompas 100 index ). Journal of Social and Human Sciences (January 2018).

Dara, S. R. dan Mariah. 2018. Faktor-Faktor yang Memengaruhi Struktur Modal pada Perusahaan Subsektor Property dan Real Estate yang terdaftar di Bursa Efek Indonesia. Jurnal Manajemen dan Bisnis 3(3):423-30.

Denziana, A. dan E. D. Yunggo. 2017. Pengaruh Profitabilitas, Struktur Aktiva, dan Ukuran Perusahaan Terhadap Struktur Modal Perusahaan pada Perusahaan Real Estate and Property yang terdaftar di Bursa Efek Indonesia tahun 2015. Jurnal Akuntansi dan Keuangan 8(1).

Dewi, D. dan G. M. Sudiartha. 2017. Pengaruh Profitabilitas, Ukuran Perusahaan, dan Pertumbuhan Aset Terhadap Struktur Modal dan Nilai Perusahaan. Jurnal Manajemen 
6(4):2222-52.

Dewi, W. dan H. S. Lestari. 2014. Faktor-Faktor Penentu Struktur Modal Perusahaan Non Keuangan Yang Terdaftar Di Bursa Efek Indonesia. Jurnal Manajemen dan Pemasaran Jasa Volume 7.

Dewiningrat, A. I, dan I. K. Mustanda. 2018. Pengaruh Likuiditas, Profitabilitas, Pertumbuhan Penjualan, Dan Struktur Aset terhadap Struktur Modal. E-Jurnal Manajemen Universitas Udayana 7(7):246016. doi: 10.24843/EJMUNUD.2018.v07.i07.p02.

Fitriani, A. Mardi, dan S. Indriani. 2014. Pengaruh risiko bisnis dan pajak terhadap struktur modal studi empiris pada perusahaan sektor." Jurnal Manajemen, Strategi Bisnis dan Kewirausahaan.

Hartati, M. S. dan H. Mukhibad. 2018. The Influence Of Profitability, Liquidity, Business Risk, Firm Size, and Sales Growth in The Property and Real Estate Companies Listed in the Idx During 2013 - 2016. Accounting Analysis Journal 7(2):103-10. doi: 10.15294/aaj.v7i2.22383.

Husnan, S. dan E. Pudjiastuti. 2015. Dasar-Dasar Manajemen Keuangan. Tujuh. Yogyakarta: UPP STIM YKPN.

Indah, N., K. Sari, K. Hendra, dan S. Nurlaela. 2018. The Effect Structure of Assets , Liquidity, Firm Size and Profitability of Capital Structure ( Empirical Study on Manufacturing Companies Listed on Indonesia Stock Exchange ). International Conference on Technology, Education, and Social Science 2018, 107-17.

Insiroh, L. 2014. Pengaruh Profitabilitas, Ukuran Perusahaan, Pertumbuhan Aset dan Struktur Aset Terhadap Struktur Modal. Jurnal Ilmu Manajemen 2.

Jusrizal, dan A. H. 2017. Faktor-Faktor yang Mempengaruhi Struktur Modal. Vol. 10.

Kur, F. A. dan A. Agbo. 2021. Determinants of capital structure in the Nigerian manufacturing sector. Journal Of Accounting (February).

Mahardika, L. A 2020. 6 Bulan Corona di Indonesia, Derita di Sektor Properti Bertubi-tubi". https://market.bisnis.com/read/20200902/192/1286301/6-bulan-corona-di-indonesia-deritadi-sektor-properti-bertubi-tubi/. diakses 4 Januari 2021

Maryanti, E. 2016. Analisis Profitabilitas, Pertumbuhan Perusahaan, Pertumbuhan Penjualan, dan Struktur Aktiva Terhadap Struktur Modal pada Perusahaan Sektor Industri Barang Konsumsi yang terdaftar di Bursa Efek Indonesia. Riset Akuntansi dan Keuangan Indonesia 1(2):143-51. doi: 10.23917/reaksi.v1i2.2730.

Matias, F., dan Z. Serrasqueiro. 2016. Are there reliable determinant factors of capital structure decisions? Empirical study of SMEs in different regions of Portugal." Research in International Business and Finance. doi: 10.1016/j.ribaf.2016.09.014. 
Mufidah, I. G. K. A. Ulupui, dan R. Prihatni. 2018. "Pengaruh Profitabilitas, Likuiditas, dan Risiko Bisnis Pada Struktur Modal Perusahaan Properti dan Real Estate di Bursa Efek Indonesia." Jurnal Manajemen, Strategi Bisnis dan Kewirausahaan 12 No 2:129-38.

Ningsih, L. 2020. Bertambah panjang, Ini Daftar Emiten Properti dalam Pusaran Pailit. http://wartaekonomi.co.id/berita305147/bertambah-panjang-ini-daftar-emiten-propertidalam-pusaran-pailit. diakses 4 Januari 2021

Nugroho, A. C. 2019. Ini 10 Saham Paling Buntung pada Desember 2019. http://market.bisnis.com/read/20191219/7/1183151/ini-10-saham-paling-buntung-padadesember-2019/. diakses 4 Januari 2021

Nur'aini, A., M. W. Endang, dan Y. Chomsatu. 2020. Pengaruh Pertumbuhan Perusahaan, Likuiditas, Resiko Bisnis, dan Struktur Asset Terhadap Struktur Modal dengan Profitabilitas sebagai Variabel Moderasi. Jurnal Kajian Pendidikan Ekonomi dan Ilmu Ekonomi IV:2536.

Rakshit, D. 2021. Determinants of corporate capital structure: a study. Journal of Business and Finance (February).

Ridho, M. 2019. Faktor-Faktor yang Memengaruhi Struktur Modal. Jurnal Ekonomi dan Bisnis 22:13-19.

Ridwan, M. dan L. A. Diyani. 2018. "Pengaruh Rasio Keuangan dan Pertumbuhan Penjualan Terhadap Harga Saham.” Jurnal Bisnis dan Komunikasi 5(1):1-7.

Riyanto, B. 2001. Dasar-dasar Pembelanjaan Perusahaan. Edisi 4. Yogyakarta: Bagian Penerbitan FE.

Rustam, M. 2015. Penentuan Struktur Modal Optimal Pada Perusahaan Sektor Properti, Real Estate , dan Kontruksi yang Terdaftar di Bursa Efek Indonesia. Jurnal Ekonomi Bisnis dan Kewirausahaan 4(1):94-124.

Sahabuddin, Z. A. 2017. Asset Structure Impact on Capital Structure of Capital Market-Listed Firms in Indonesia and Malaysia. Jurnal Keuangan dan Perbankan 21(040):376-86.

Sari, S. D. 2016. Pengaruh Risiko Bisnis, Life Cycle Dan Diversifikasi Terhadap Struktur Modal Serta Hubungannya Dengan Nilai Perusahaan Manufaktur Di Indonesia. Jurnal Manajemen Teori dan Terapan Journal of Theory and Applied Management 9(1):58-77. doi: 10.20473/jmtt.v9i1.2787.

Sjahrial, D. 2007. Manajemen Keuangan. Jakarta: Mitra Wacana Media.

Srimindarti, C. dan P. Hardiningsih. 2015. Pengaruh struktur asset perusahaan terhadap struktur modal dimoderasi profitabilitas. Jurnal Ilmiah (20). 
Sulindawati, N. L. G. E., G. A. Yuniarta, dan I. G. A. Purnamawati. 2017. Manajemen Keuangan: Sebagai Dasar Pengambilan Keputusan Bisnis. Depok: PT RajaGrafindo Persada.

Sutarka, W., dan A. Hanafi. 2018. The Determinants of Capital Structure of Listed Retailing Sector Companies on Indonesia Stock Exchange (IDX ). Vol. 2.

Suwardjono. 2005. Teori Akuntansi: Perekayasaan Pelaporan Keuangan. Yogyakarta: BPFE Yogyakarta.

Suweta, N. M. N. P. Dewi, dan M. R. Dewi. 2016. Pengaruh Pertumbuhan Penjualan, Struktur Aktiva dan Pertumbuhan Aktiva Terhadap Struktur Modal. Jurnal Manajemen 5(8):517299.

Wardani, O. M., dan Subowo. 2020. Factors That Influence Capital Structure With Profitability as A Moderating Variable. Accounting Analysis Journal 9(2):103-4. doi: 10.15294/aaj.v9i2.30541.

Yohanes. 2014. Faktor-Faktor Yang Mempengaruhi Struktur Modal Pada Perusahaan Non Keuangan Yang Publik. Jurnal Bisnis dan Akuntansi 16(1a):133-48. 